\title{
FENOLOŠKA SVOJSTVA LISTANJA POLJSKOG JASENA (FRAXINUS ANGUSTIFOLIA VAHL) U KLONSKOJ SJEMENSKOJ PLANTAŽI
}

\author{
LEAF PHENOLOGY CHARACTERISTICS OF \\ NARROW-LEAVED ASH (Fraxinus angustifolia Vahl) \\ IN CLONAL SEED ORCHARD
}

Ivan ANDRIĆ ${ }^{1}$ Igor POLJAK', Marno MILOTIĆ ${ }^{2}$ Marilena IDŽOJTIĆ ${ }^{\text {, Davorin KAJBA }}$

\begin{abstract}
Sažetak
U tri godine istraživanja (2012., 2014. i 2015.) praćene su fenološke karakteristike listanja poljskog jasena (Fraxinus angustifolia Vahl) u klonskoj sjemenskoj plantaži Nova Gradiška. Motrenjem su obuhvaćena 42 klona s četiri ramete po klonu (ukupno 168 biljaka) porijeklom iz triju populacija (Jasenovac, Novska i Stara Gradiška). Razvoj lista podijeljen je na šest fenofaza, međutim u radu je analizirana isključivo faza L2 (početak listanja). Prosječni broj dana od 1. siječnja do početka listanja iznosio je 98 dana u 2012. godini, 93 dana u 2014. godini i 103 dana tijekom 2015. godine. Prosječan broj dana koji je bio potreban za razvoj lista u 2012. godini iznosio je 27 dana, u 2014. godini 26 dana, dok je u 2015. godini bio 20 dana. Na osnovi fenoloških rezultata klonovi su podijeljeni na dvije ekotipske forme: ranu i kasnu. Prosječne vrijednosti broja dana s obzirom na početak listanja iznosile su od 90 do 101 dan za ranu ekotipsku formu te od 99 do 107 dana za kasnu. U radu je dokazana visoka povezanost između kumulativnih vrijednosti količine oborina (od 1. prosinca do nastupanja faze L2) i početka listanja. Istraživanjem je utvrđena statistički značajna razlika između svih istraživanih klonova, između klonova unutar populacija, kao i između istraživanih ekotipskih formi. Statistički značajna međupopulacijska varijabilnost nije utvrđena. Unutarklonska varijabilnost smanjivala se sa starošću sjemenske plantaže, što ukazuje na veću stabilnost i ujednačenost fenoloških karakteristika između rameta s povećanjem njihove starosti. Pripadnost klonova ekotipskim formama nije pratila njihovo geografsko porijeklo, čime je dodatno potvrđena značajna unutarpopulacijska varijabilnost poljskog jasena.
\end{abstract}

KLJUČNE RIJEČI: početak listanja, oborine, unutarpopulacijska i međupopulacijska varijabilnost, unutarklonska varijabilnost, rana i kasna ekotipska forma

\section{UVOD}

INTRODUCTION

Poljski jasen (Fraxinus angustifolia Vahl) jedna je od tri autohtone vrste jasena u Europi. Njegov areal proteže se od
Španjolske i Portugala na zapadu, sjeverno prema Slovačkoj i južnoj Moravskoj, a istočno prema Turskoj, Siriji, Kavkazu, Iranu i južnoj Rusiji. U Hrvatskoj najveće kontinuirane sastojine poljskog jasena nalazimo uz rijeku Savu ( $80 \%$ ), gdje raste na dubokim, ilovastim i vlažnim tlima s povremenim

\footnotetext{
${ }^{1}$ Ivan Andrić, mag. ing. silv., dr. sc. Igor Poljak, prof. dr. sc. Marilena Idžojtić, prof. dr. sc. Davorin Kajba, Zavod za Šumarsku genetiku, dendrologiju i botaniku, Šumarski fakultet Sveučilišta u Zagrebu, Svetošimunska 25, Zagreb, Hrvatska, e-mail: davorinkajba@gmail.com

2 Marno Milotić, mag. ing. silv., Zavod za zaštitu šuma i lovno gospodarenje, Šumarski fakultet Sveučilišta u Zagrebu, Svetošimunska 25, Zagreb, Hrvatska
} 
plavljenjem (Fukarek 1983; Anić 1999, 2001). Ako pionirske vrste definiramo kao eurivalentne s obzirom na ekološke čimbenike odlučujuće za njihovo uspijevanje i pomlađivanje, tada je poljski jasen pionirska vrsta, iako ima i osobina prijelazne (intermedijarne) vrste.

Poljski jasen lista nakon cvjetanja. Usporedimo li fenologiju cvjetanja i listanja, tada su trendovi dosta slični, s tim da listanje karakterizira dosta manja varijabilnost između različitih geografskih područja. U mediteranskim zemljama s listanjem počinje od sredine ožujka do sredine svibnja i vegetacijski period je dulji, a u srednjoj Europi s listanjem počinje od kraja ožujka do sredine svibnja i vegetacijski period je nešto kraći (Fraxigen 2005).

Listanje je kompleksan fiziološki proces koji je s jedne strane uvjetovan unutarnjim genetičkim naslijeđem jedinke, a s druge strane okolišnim uvjetima u kojima jedinka raste i razvija se. Globalnim zatopljenjem kao klimatskim fenomenom koji Zemlju prati zadnjih stotinjak godina fenologija ponovno dobiva na važnosti i svrsishodnosti. Klima ima važnu ulogu u mnogim biološkim procesima kao što su dinamika vegetacijskog razdoblja, štete od proljetnih i jesenskih mrazeva, balans ugljika u ekosustavu, i upravo zbog toga je vegetacija onaj prirodni element koji nam može ukazati i dati povratne informacije o tendenciji klimatskih promjena (Menzel 2000).

Fenološka motrenja sastoje se od utvrđivanja datuma početka nicanja, listanja, pupanja, cvjetanja, plodonošenja i dr. Iz prikupljenih fenoloških podataka višegodišnjih biljaka, koje su ujedno i najprikladnije za proučavanje feno- loških svojstava, proučava se utjecaj klimatskih varijacija te spoznaje kako biljke reagiraju na nju (Jelić i Vučetić 2011). Još u 18. stoljeću de Réaumur (1735) je utvrdio da na fenološke pojave (listanje, cvjetanje) najveći utjecaj imaju kumulativne temperature prije nastupa ispoljavanja fenoloških svojstava. Od tada je identificirano još nekoliko čimbenika koji utječu na ispoljavanje fenoloških svojstava, poput duljine hladnog perioda (Murray i sur. 1989; Sogaard i sur. 2008; Laube i sur. 2014), fotoperiod (Heide 1993; Körner i Basler 2010; Caffarra i Donnelly 2011; Basler i Körner 2012; Laube i sur. 2014), temperature prethodne jeseni (Heide 2003), dostupnost hranjiva u tlu (Jochner i sur. 2013), oborine (Penuelas i sur. 2002; Estiarte i sur. 2011) i režim svjetla (Linkosalo i Lechowicz 2006).

Veće količine oborina prije vegetacijske sezone mogu povisiti potrebu za toplinskim sumama (Fu i sur. 2014), što potvrđuje da oborine mogu također neizravno doprinijeti na početak listanja. Utjecaj oborina na početak listanja izraženiji je nakon suhe zime, gdje upravo količina oborina u proljetnom periodu predstavlja jedini dostupni izvor vode biljkama (Shen i sur. 2015).

Kod većih poplava u Posavini tijekom mirovanja vegetacije, voda ostaje u šumi i više od mjesec dana. Visoki vodostaji Save (primjerice kod Jasenovca u razdoblju od 1960.-1990. godine) izmjereni su u ožujku i travnju te u listopadu, studenome i prosincu, dok su niski vodostaji zabilježeni od lipnja do listopada, a rjeđe tijekom veljače (Prpić i sur. 2005).

Varijabilnost svojstva listanja govori nam koliko to svojstvo ima tendenciju razlikovanja, kao odgovor na okolinu i uku-

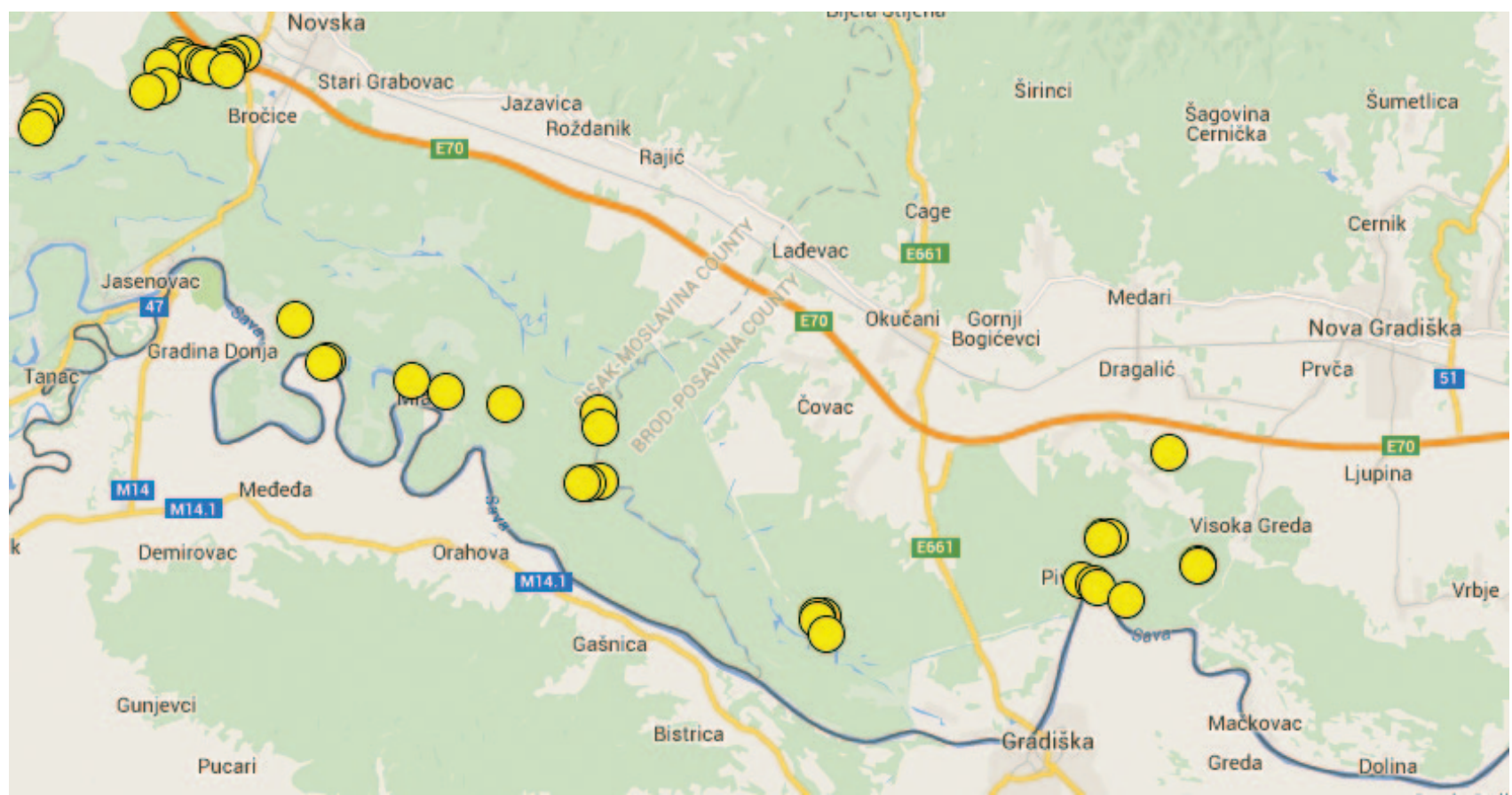

Slika 1. Rasprostranjenost i položaj istraživanih klonova poljskog jasena

Figure 1 Distribution and location of the selected clones of narrow-leaved ash 
pno genetičko naslijeđe koje jedinke posjeduju. Unutarpopulacijska i međupopulacijska genetička varijabilnost značajna je za održavanje biološke raznolikosti te za dugoročnu adaptaciju u promjenjivim uvjetima sredine u kojoj jedinka odnosno populacija egzistira.

U kontekstu globalne promjene klime, važno je poznavati strukturu genetičke raznolikosti, posebice s obzirom na tzv. adaptivna svojstva kao što su rast, preživljavanje i fenologija listanja (Ivanković i sur. 2011; Ballian i sur. 2015). Adaptivna svojstva koja se ogledaju kroz fenotipske osobine evoluirala su kroz lokalne prilagodbe te se prenose s generacije na generaciju s osnovnom svrhom opstanka vrste ili povećanja životne sposobnosti (Kremer i sur. 2012).

Cilj istraživanja je analizirati početak listanja (L2 faza), duljinu razvoja lista (L2-L6), utjecaj atmosferskih čimbenika na početak listanja, unutarpopulacijsku i međupopulacijsku varijabilnost, unutarklonsku varijabilnost, kao i postojanje ekotipskih formi s obzirom na početak listanja. Istraživanja su provedena u klonskoj sjemenskoj plantaži Šumarije Nova Gradiška, a genotipovi potječu iz različitih lokaliteta sjemenske regije srednja Posavina (Slika 1).

\section{MATERIJALI I METODE}

\section{MATERIALS AND METHODES}

\section{Područje istraživanja - Study area}

Klonska sjemenska plantaža poljskog jasena osnovana je 2005. godine na području UŠP Nova Gradiška, Šumarije Nova Gradiška na površini od 3,5 ha. Pripada sjemenskoj regiji srednje Posavine. Smještena je južno od željezničke pruge Zagreb-Vinkovci u blizini sela Prvča (N 45 $15^{\circ}$ 9, ““; E $\left.17^{\circ} 21^{\prime} 44,5^{\prime \prime}\right)$. Plantaža ukupno sadrži 56 klonova, a razmak sadnje iznosi $4 \times 4 \mathrm{~m}$. Plus stabla su selekcionirana na osnovi svojih fenotipskih karakteristika u gospodarskim jedinicama: Grede Kamare i Krapje Đol (Šumarija Jasenovac),
Trstika (Šumarija Novska), Ljeskovače i Podložje (Šumarija Stara Gradiška), iz ukupno 32 odjela/odsjeka. Razmak između selekcioniranih stabala bio je veći od $50 \mathrm{~m}$, čime je isključeno uzorkovanje genetički srodstvenih jedinki (Kajba i sur. 2008). Shema rasporeda klonova (rameta) unutar plantaže predstavlja klasičan randomizirani način razmještaja, $s$ tim da je osnovno pravilo da pripadajuće ramete istoga klona moraju biti međusobno što udaljenije iz razloga negativne polinacije, odnosno mogućeg oprašivanja u srodstvu.

Istraživano područje karakterizira umjerena kontinentalna klima, koja je značajno modificirana utjecajem gorskog masiva Psunj, a donekle i Babje gore. Hod temperatura, padalina, insolacije, magle i mrazeva, ukazuje na kontinentalnost, koja je kao takva karakteristična za prijelazno panonsko područje - od središnje Panonske nizine prema južnom peripanonskom području. Zime su u pravilu razmjerno oštre, dok su ljeta vruća. Srednja godišnja temperatura zraka iznosi između 10,5 i $11^{\circ} \mathrm{C}$. Prosječna količina godišnjih padalina je između 813 i $820 \mathrm{~mm} / \mathrm{m}^{2}$. Mraz je redovita pojava te njegova kasna pojava u proljeće može nanijeti velike štete u voćarstvu, ratarstvu i šumarstvu.

\section{Fenološka motrenja - Phenology monitoring}

$\mathrm{S}$ fenološkim motrenjem u klonskoj sjemenskoj plantaži poljskog jasena Nova Gradiška započelo se 2012. godine te se nastavilo 2014. i 2015. godine. Motrenjem su obuhvaćena 42 klona, s tim da su od svakog klona izabrane po četiri ramete (ukupno 168 jedinki). Prilikom odabira biljaka na kojima će se obavljati motrenje, vodilo se računa da su biljke podjednakog promjera i uzgojnog oblika. Ramete su obilježene te su svake godine jednakim redoslijedom motrene kako bi rezultati bili što usporedljiviji. Treba istaknuti da su sva opažanja obavljena od istih motritelja, čime je greška individualne procjene svedena na minimum. Za što preciznije i lakše motrenje neophodno je bilo odrediti točne faze
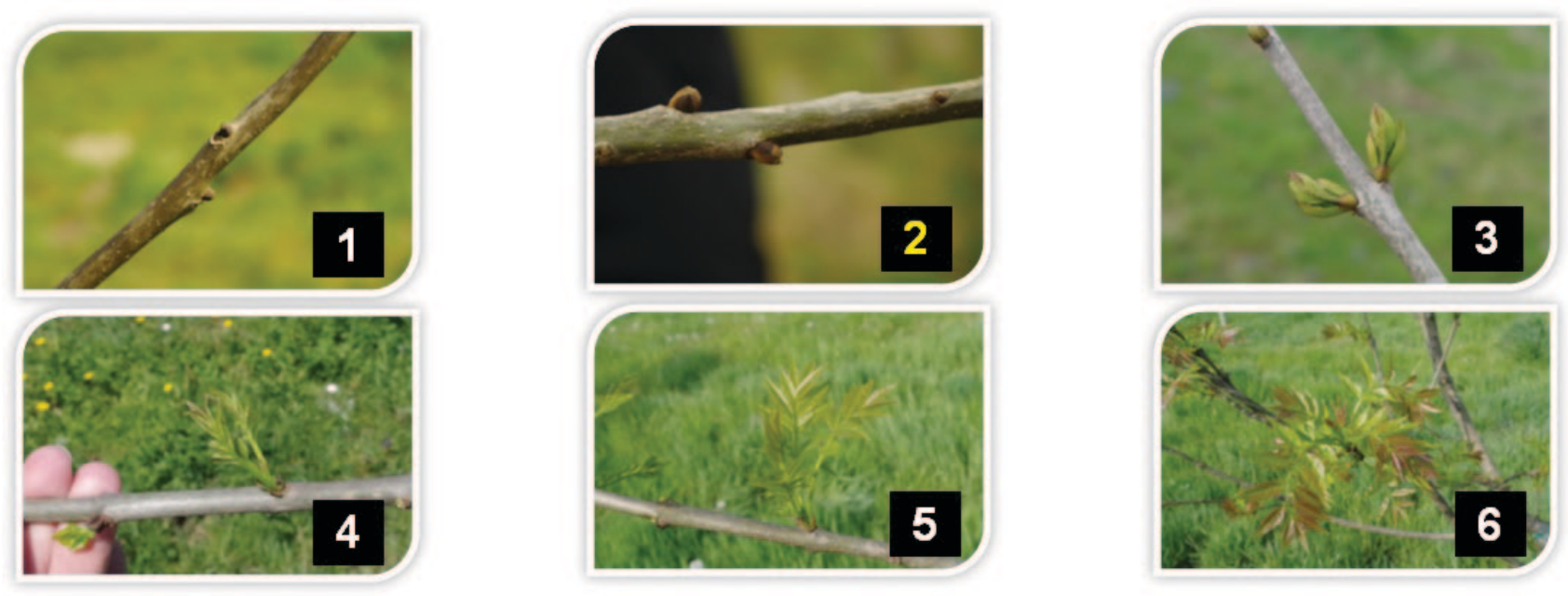

Slika 2. Razvojne faze listanja poljskog jasena

Figure 2 Leaf phenology phases of narrow-leaved ash 
Tablica 1. Opis fenofaza listanja poljskog jasena

Table 1 Description of leaf phenlogy phases of narrow-leaved ash

Faza
Phase $\begin{aligned} & \text { Opis faze } \\ & \text { L1 } \quad \begin{array}{l}\text { Desription of phase } \\ \text { dormant buds } \\ \text { faza bubrenja, pup veći (ne i nužno), mekan, svjetlo smeđe do zelenkaste boje. Mogu se uočiti malo razmaknute ljuske pupa, ali se još uvijek } \\ \text { ne vide vršci ljuski } \\ \text { swelled buds }\end{array} \\ & \text { L3 } \begin{array}{l}\text { otvoren pup, na vrhu pupa ljuske razmaknute te vidljivi vršci liski (crvene ili zelene boje) } \\ \text { bud burst } \\ \text { vidljive skupljene liske, pri dnu se još mogu vidjeti ostaci razmaknutih ljuski pupa, boja još uvijek nije potpuno zelena (ukoliko je u L3 fazi bila } \\ \text { crvene boje) } \\ \text { small, completely folded leaves } \\ \text { list zelene boje, liske se razdvajaju od vrha na niže, plojke liski nisu još potpuno otvorene } \\ \text { leaves partially folded, uncompletely flushed } \\ \text { L5 list potpuno razvijen (jasno vidljive sve morfometrijske karakteristike potpuno razvijenog lista) iako još nije dosegao punu veličinu, plojke liski } \\ \text { su potpuno ispravljene } \\ \text { developed leaves (the end of flushing) }\end{array}\end{aligned}$

koje će se bilježiti te izraditi klasifikacijski manual sa svim fenološkim fazama listanja. Listanje je podijeljeno na šest razvojnih faza na osnovi kojih je napravljen model prema kojem se motrenje vršilo u sve tri godine istraživanja (Slika 2, Tablica 1). Opažanja su obavljana jednom tjedno od mjeseca ožujka u pravilnim intervalima, sve dok i posljednja biljka (rameta) nije došla u L6 razvojnu fazu (mjesec svibanj). U terenskim manualima za svaki datum motrenja biljkama su dodijeljene aktualne razvojne faze. $\mathrm{U}$ radu je analizirana isključivo faza L2 (početak listanja).

\section{Statistička obrada podataka-Statistical analysis}

Nakon obavljenog motrenja datumi nastupanja pojedine fenološke faze zamijenjeni su brojkama - brojem dana od 1. siječnja do datuma nastupa određene faze (u ovom radu do pojave faze L2). Za svojstva početka listanja, duljine razvoja lista i utjecaja oborina na početak listanja te za usporedbu početka listanja unutar i između populacija, kao i za međuklonsku i unutarklonsku varijabilnost svaka istraživana godina analizirana je zasebno. Kod razvrstavanja klonova u ekotipske forme, svakom klonu dodijeljena je prosječna vrijednost rameta kroz sve tri istraživane godine za svojstvo početka listanja.

Svojstvo početka listanja analizirano je i prikazano kroz standardne deskriptivne statističke parametre (srednja vrijednost, standardna pogreška srednje vrijednosti, standardna devijacija, koeficijent varijabilnosti). Povezanost između kumulativnih oborina temperature i insolacije $s$ početkom listanja utvrđena je koeficijentom korelacije (r). Kako bi se utvrdile razlike između ekotipskih formi, klonova i godina istraživanja korištena je analiza varijance (ANOVA). Kod utvrđivanja međupopulacijske i unutarpopulacijske varijabilnosti analizirani faktori bili su populacija (šumarija) i klon, i to tako da je faktor klon ugniježđen unutar faktora populacija. Pripadnost klonova ekotipskim formama sobzirom na početak listanja (rana i kasna) utvrđena je algoritmom za klasifikaciju objekata u klastere, tzv. $k$-means klaster analizom. Sve navedene statističke analize provedene su pomoću statističkog programa STATISTICA (StatSoft, Inc. 2011).

\section{REZULTATI RESULTS}

Srednje vrijednosti početka listanja poljskog jasena po godinama za sve klonove zajedno i za ekotipske forme prikazane su u tablici 2. Prosječni broj dana od 1. siječnja do početka listanja iznosio je 98 dana u 2012. godini, 93 dana u 2014. godini i 103 dana tijekom 2015. godine. Istraživanjem su utvrđene statistički značajne razlike u početku listanja poljskog jasena po istraživanim godinama $(\mathrm{F}=160,57$; $\mathrm{p}<0,0001)$. Prosječne vrijednosti početka listanja, standardne pogreške sredine te standardne devijacije za sve istraživane klonove prikazane su na slici 3. Duljina razvoja lista podrazumijeva razdoblje od otvaranja pupa (faza L2) pa do zadnje razvojne faze (faza L6) u kojoj list još nije posti-

Tablica 2. Početak listanja poljskog jasena

Table 2 Beginning of leaf unfolding of narrow-leaved ash

\begin{tabular}{|c|c|c|c|}
\hline \multirow{2}{*}{$\begin{array}{l}\text { Godine } \\
\text { Years }\end{array}$} & \multicolumn{3}{|c|}{$\begin{array}{l}\text { Srednje vrijednosti početka listanja (u danima od 01.siječnja) } \\
\text { Mean value of leaf unfolding (no. of days from } 1^{\text {st }} \text { January) }\end{array}$} \\
\hline & $\begin{array}{l}\text { Svi klonovi } \\
\text { All clones }\end{array}$ & $\begin{array}{l}\text { Rane forme } \\
\text { Early forms }\end{array}$ & $\begin{array}{l}\text { Kasne forme } \\
\text { Late forms }\end{array}$ \\
\hline 2012 & 98 & 94 & 102 \\
\hline 2014 & 93 & 90 & 99 \\
\hline 2015 & 103 & 101 & 107 \\
\hline
\end{tabular}



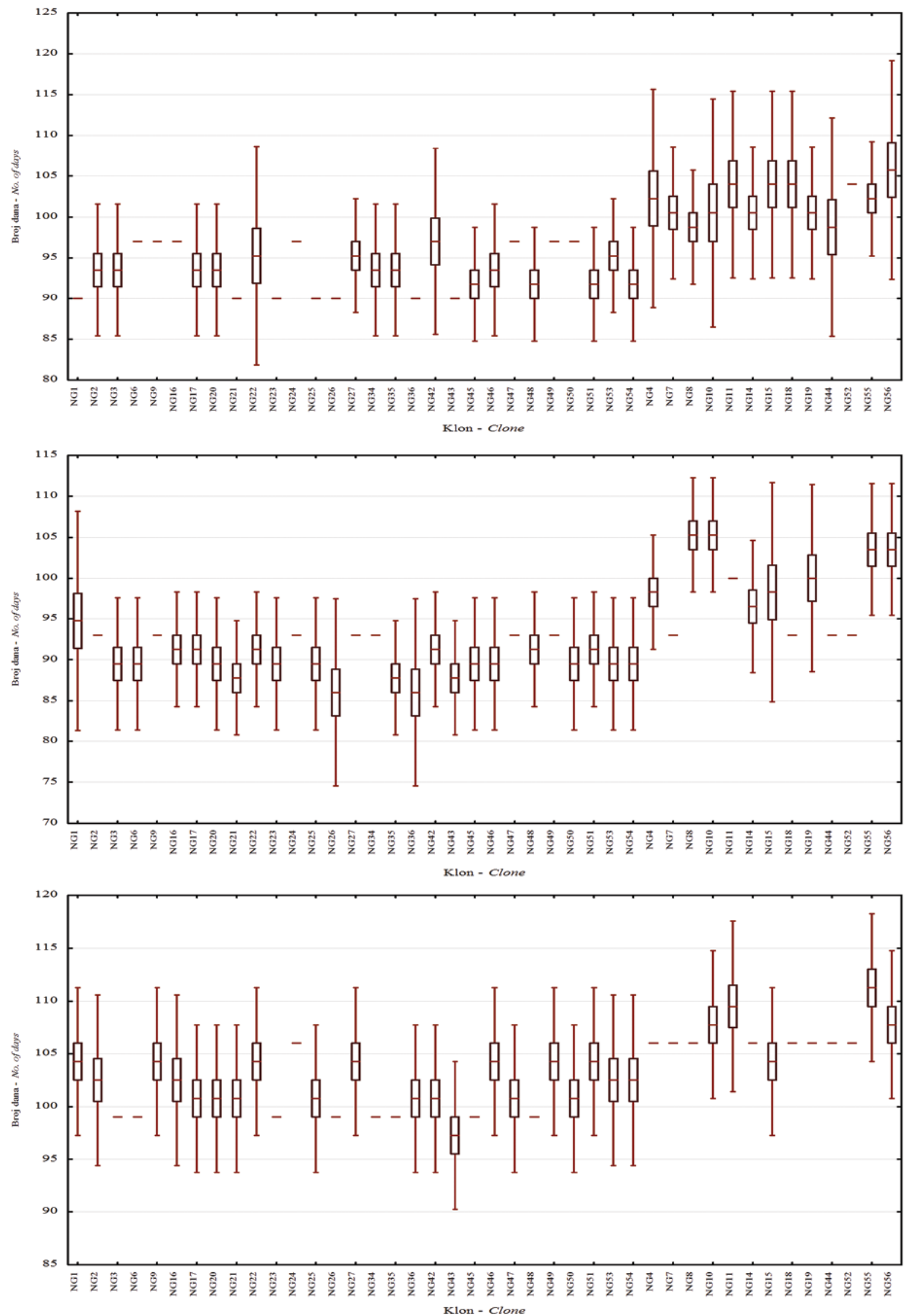

Slika 3. Prosječan broj dana po klonovima potreban za početak listanja za sve tri istraživane godine $(2012,2014,2015)$. Horizontalna crtica prikazuje aritmetičku sredinu, pravokutnik (box) prikazuje standardnu pogrešku sredine, a vertikalne linije (whiskers) standardnu devijaciju

Figure 3 Average number of days per clones required for leaf unfolding for all three investigation years $(2012,2014,2015)$. Horizontal hyphen represents the aritmethic mean of the clone in certain year, the box represents the standard error of the mean, and whiskers the standard deviation 


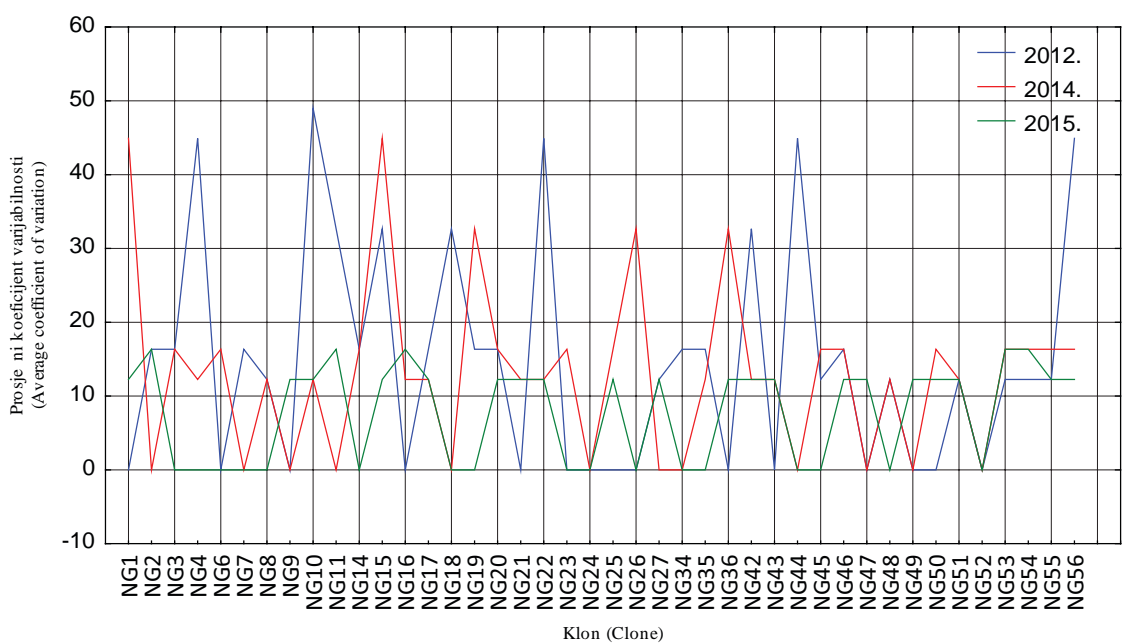

Slika 4. Prosječni koeficijenti unutarklonske varijabilnosti (\%) za promatrano svojstvo početka listanja kroz sve tri istraživane godine Figure 4 Average coefficients of intraclonal variation (\%) of the observed trait leaf unfolding for all three investigation years
Tablica 3. Analiza varijance (ANOVA)

Table 3 Analysis of variance (ANOVA)

\begin{tabular}{|c|c|c|c|c|}
\hline \multirow{2}{*}{$\begin{array}{l}\text { Izvor } \\
\text { varijabilnosti } \\
\text { Source of } \\
\text { variability }\end{array}$} & \multirow{2}{*}{$\begin{array}{l}\text { Stupnjevi } \\
\text { slobode } \\
\text { Degrees of } \\
\text { freedom }\end{array}$} & \multicolumn{3}{|c|}{$\begin{array}{c}\text { Godina (F vrijednost) } \\
\text { Year (F value) }\end{array}$} \\
\hline & & 2012. & 2104. & 2015. \\
\hline $\begin{array}{l}\text { Ekotip } \\
\text { Ecotype }\end{array}$ & 1 & $144,55^{* * *}$ & $121,96^{* * *}$ & $99,65^{* * *}$ \\
\hline $\begin{array}{l}\text { Klon } \\
\text { Clone }\end{array}$ & 41 & $5,95 * * *$ & $7,57^{* * *}$ & $5,66^{* * *}$ \\
\hline $\begin{array}{l}\text { Populacija } \\
\text { Population }\end{array}$ & 2 & $0,43^{\text {ns }}$ & $2,04^{\mathrm{ns}}$ & $0,27^{\mathrm{ns}}$ \\
\hline $\begin{array}{l}\text { Klon (Populacija) } \\
\text { Clone (Population) }\end{array}$ & 39 & $6,12^{* * *}$ & $7,20^{* * *}$ & $5,87^{* * *}$ \\
\hline
\end{tabular}

gao svoju konačnu veličinu, ali se jasno razlikuju sva morfološka obilježja potpunog razvijenog lista. Prosječan broj dana koji je bio potreban za razvoj lista u 2012. godini izno- sio je 27 dana, u 2014. godini 26 dana, dok u 2015. godini 20 dana.

Vrijednosti početka listanja po godinama istraživanja stavljene su u korelaciju s kumulativnim oborinama, temperaturama i insolacijom, čije su vrijednosti računate od tri različita početna datuma (1. studeni, 1. prosinac, 1. siječanj) pa sve do početka listanja. Vrijednosti koeficijenta korelacije za parametar kumulativnih oborina iznosile su: $r=-0,19$ od 1 . studenog, $r=0,93$ od 1 . prosinca i $r=0,08$ od 1. siječnja. Za parametar kumulativnih srednjih dnevnih temperatura vrijednosti su: $r=-0,00$ od 1 . studenog, $r=-$ 0,32 od 1. prosinca i $r=0,49$ od 1 . siječnja. Za parametar kumulativnih vrijednosti insolacije vrijednosti su sljedeće: $\mathrm{r}=0,70$ od 1 . studenog, $r=0,61$ od 1 . prosinca i $r=0,03$ od 1. siječnja.

Koeficijenti varijabilnosti (CV \%) smanjivali su se sa starošću pokusa, pri čemu su prosječne vrijednosti iznosile: $15,22 \%$ u dobi $2+8$ god., $13,46 \%$ u dobi $2+10$ god. i

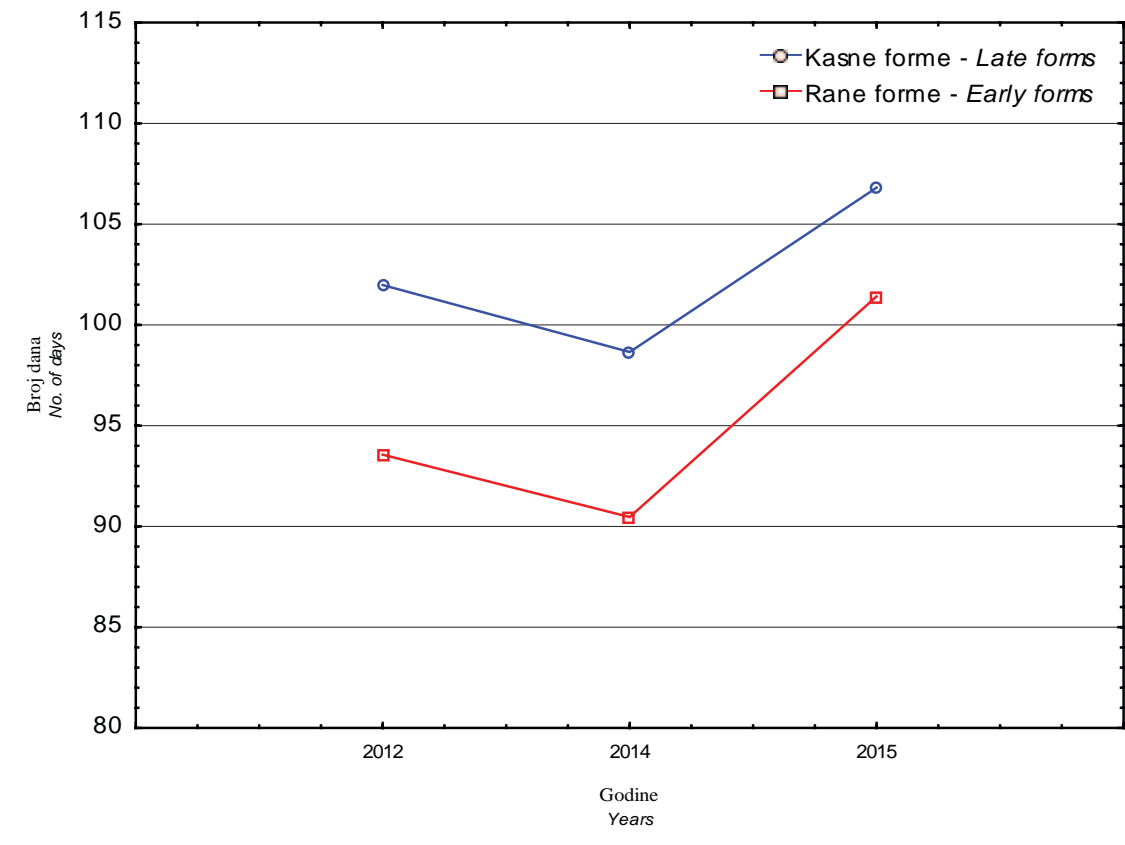

Slika 5. Ekotipske fenoforme poljskog jasena Figure 5 Ecotypic phenoforms of narrow-leaved ash 
Tablica 4. Pripadnost klonova ekotipskim formama

Table 4 Grouping clones by ecotypic forms

\begin{tabular}{ll}
$\begin{array}{l}\text { Ekotipske forme } \\
\text { Ecotypic forms }\end{array}$ & \multicolumn{1}{c}{$\begin{array}{c}\text { Klonovi } \\
\text { Clones }\end{array}$} \\
$\begin{array}{l}\text { Rana ekotipska forma } \\
\begin{array}{l}\text { Early ecotypic form } \\
\text { Kasna ekotipska forma }\end{array}\end{array}$ & $\mathrm{NG} 43, \mathrm{NG}$, NG, NG46, NG47, NG48, NG49, NG50, NG51, NG53, NG54 \\
$\begin{array}{l}\text { Late ecotypic form } \\
\text { NG4, NG7, NG8, NG10, NG11, NG14, NG15, NG18, NG19, NG44, NG52, NG55, NG56 }\end{array}$
\end{tabular}

$7,80 \% \operatorname{kod} 2+11$ god. Koeficijenti varijabilnosti po klonovima i godinama prikazani su na slici 4 .

Analizom varijance za sve istraživane klonove, neovisno o njihovu porijeklu, ustanovljena je statistički značajna međuklonska varijabilnost ili individualna varijabilnost. Statistički značajne razlike utvrđene su i na razini unutarpopulacijske varijabilnosti, dok međupopulacijska varijabilnost nije statistički značajna (tablica 3 ).

Klonovima je dodijeljena srednja vrijednost svih njihovih rameta kroz sve tri istraživane godine. $K$-means klaster metodom klonovi su razvrstani na dvije ekotipske forme (rana i kasna) s obzirom na početak listanja (Slika 5). Od ukupno 42 klona na kojima su vršena fenološka motrenja, ranoj ekotipskoj formi pripada 29 klonova, dok kasnoj ekotipskoj formi pripada 13 klonova (tablica 4). Opravdanost podjele klonova na dvije ekotipske forme dokazana je analizom varijance gdje je ustanovljena statistički značajna razlika između formi (tablica 3).

\section{RASPRAVA}

\section{DISCUSSION}

Izučavanjem fenoloških i kvantitativnih svojstava poljskog jasena dobiva se bolji uvid u genetičku konstituciju vrste, a samim time i bolje razumijevanje njegove adaptacijske sposobnosti na stanišne uvjete u kojima prirodno pridolazi. Hänninen (1990) ističe dvije vrste adaptacije: adaptacija preživljavanja, koja podrazumijeva sposobnost jedinke da preživi izmijenjene okolišne uvjete i adaptaciju kapaciteta koja podrazumijeva sposobnost jedinke da učinkovito iskoristi sve raspoložive resurse u svom okolišu. Fenološka svojstva su važna svojstva za oba tipa adaptacije, jer obilježavaju prijelaz iz faze mirovanja, otpornost u aktivnoj fazi, a ponajviše ranjivost u odnosu na nepovoljne uvjete okoliša. Nadalje, ako vrste šumskog drveća različito reagiraju na promjenu globalne klime, doći će do promjene konkurentskih odnosa između vrsta, a samim time i do promjene sastava šumskih ekosustava i pomicanja granica areala pojedinih vrsta (Kramer i sur. 2000).

Rezultati fenoloških istraživanja početka listanja poljskog jasena u klonskoj sjemenskoj plantaži Nova Gradiška pokazali su značajne razlike u vremenu početka listanja kroz istraživane godine, što je potvrđeno i provedenom analizom varijance. Značajne razlike u početku listanja poljskog jasena po istraživanim godinama uvjetovane su različitim klimatskim obilježjima kroz godine u periodu prije nastupa listanja (temperature, oborine, insolacija i dr.). Evidentno značajniji pomak svih klonova u početku listanja za 2015. godinu najvjerojatnije je uvjetovan većom količinom oborina u razdoblju prije ispoljavanja svojstva. Preciznije determiniranje onih atmosferskih parametara koji zasebno ili u sinergiji imaju najveći utjecaj na početak listanja omogućit će nam u budućnosti i preciznije predviđanje ispoljavanja toga svojstva, a samim time i razumijevanja drugih živih organizama čija je ekologija usko vezana za listanje pojedinih šumskih vrsta drveća.

Poljski jasen kao pionirska vrsta u nizinskim šumskim ekosustavima uspijeva na plavljenim do močvarnim staništima koja su često nepovoljna za ostale vrste drveća, tako da gotovo nema konkurencije (Anić 1999). Uvjeti takvih staništa, iz generacije u generaciju oblikovali su genetsku konstituciju vrste, utjecali na ekspresiju kvantitativnih svojstava, a prirodna selekcija je uvjetovala fiksiranje adaptivnih svojstava. Informaciju o visokoj saturiranosti pedološkog profila te prilagodbu na nju, prenosi i na staništa koja su izvan dosega poplavnih voda. Kompleksnost utjecaja većeg broja čimbenika na početak listanja otvara komplikacije u predviđanju i modeliranju istog. No, režim oborina i dostupnost vode u tlu svakako treba promatrati kao važan čimbenik koji može signifikatno utjecati na ispoljavanje fenoloških svojstava u šumskim ekosustavima (Peneulas i sur. 2004). Utjecaj meteoroloških prilika nije negativno djelovalo na trušenje peludi kod klonova hrasta lužnjaka, dok su velika kolebanja temperature zraka, uz pad vlažnosti zraka, prekinule receptivnost ženskih cvijetova (Franjić i sur. 2011). U radu su istraživana tri atmosferska parametra: temperatura, oborine i insolacija. Njihove kumulativne vrijednosti od tri različita početna datuma zbrajanja stavljene su u korelaciju s vrijednostima početka listanja. Korelacijskom analizom utvrđeno je da su kumulativne oborine od 1 . prosinca $(\mathrm{r}=0,93)$ i insolacija od 1 . studenog $(\mathrm{r}=0,70)$ imali najveću povezanost $s$ vrijednostima početka listanja.

Istraživanjem varijabilnosti provenijencija poljskog jasena iz područja Posavine, Podravine i submediterana utvrđeno je postojanje statistički značajne unutarpopulacijske varijabilnosti za većinu istraživanih svojstava, dok se kasnolista- 
juća populacija Stara Gradiška izdvajala od ostalih posavskih populacija vjerojatno iz razloga postojanja genetskog drifta i/ili selekcijskog pritiska utjecaja kasnih mrazeva (Bogdan i sur. 2007). Utvrđena struktura genetičke varijabilnosti pokazuje da poljski jasen u području Posavine ne ispoljava klinalnu vrijednost niti ekotipsku varijabilnost, te da je dominantni udio genetičke varijabilnosti na unutarpopulacijskoj razini (Bogdan 2006). Istraživanja u ovome radu utvrdila su da je fenološko svojstvo početka listanja u klonskoj sjemenskoj plantaži poljskog jasena iskazalo statistički značajne razlike između svih istraživanih klonova uz također statistički značajnu unutarpopulacijsku varijabilnost, no te razlike nisu dobivene između istraživanih populacija (Jasenovac, Novska i Stara Gradiška). Sjeme poljskog jasena rasprostire se vodenim tokovima i poplavnom vodom na veće udaljenosti te taj selekcijski pritisak uvelike ide u prilog postojanju značajnih unutarpopulacijskih razlika u ispoljavanju svojstva početka listanja. Temunović (2013) utvrđuje da su populacije poljskog jasena u Hrvatskoj geografski jasno strukturirane, kao i to da se odlikuju visokom genetičkom raznolikošću i niskom diferencijacijom u kontinentalnoj regiji te signifikantno nižom genetičkom raznolikošću i povećanom divergencijom u mediteranskoj regiji. Visoki koeficijenti varijabilnosti u ovome istraživanju upućivali su i na visok stupanj unutarklonske varijabilnosti. Osim toga, koeficijenti varijabilnosti smanjivali su se sa starošću pokusa, što ukazuje na veću stabilnost i ujednačenost fenoloških karakteristika između rameta s povećanjem njihove starosti.Postojanje unutarpopulacijske varijabilnosti kod poljskog jasena postaje značajnije zbog pojave odumiranja jasena pojavom gljivične bolesti Hymenoscyphus fraxineus (T. Kowalski) Baral, Queloz \& Hosoya (anamorf Chalara fraxinea T. Kowalski), koja uzrokuje štetu na jasenima u mnogim dijelovima Europe (Gross i sur. 2012). Istraživanja u skandinavskim i baltičkim zemljama utvrdila su da u klonskim plantažama postoje genotipovi koji su iskazivali manju osjetljivost uz prisutnost znatne fenotipske varijabilnosti (McKinney i sur. 2011; Pliura i sur. 2011; Kjaer i sur. 2012; Stener 2013). Fenološka opažanja kao što je npr. ranije odbacivanje lišća može biti i mehanizam pasivne rezistentnosti kod određenih genotipova, $i$ to iz razloga što neinficirani i inficirani listovi mogu biti odbačeni prije nego što je $H$. fraxineus uspio prodrijeti u izbojak i stanice drva u okolini baze lista (McKinney i sur. 2012). Utvrđivanje postojanja ranih i kasnih genotipova u klonskoj sjemenkoj plantaži poljskog jasena s obzirom na početak listanja može biti od velikog značenja pri selekciji manje osjetljivih klonova na infekciju ovog patogena. U radu su klonovi podijeljeni na dvije ekotipske forme (rana i kasna), pri čemu ranoj formi pripada 29, a kasnoj 13 klonova. Pripadnost klonova ekotipskim formama nije pratilo njihovo geografsko porijeklo, čime je dodatno potvrđena značajna unutarpopulacijska varijabilnost poljskog jasena.
Osim toga, koeficijenti varijabilnosti smanjivali su se sa starošću pokusa, što ukazuje na veću stabilnost i ujednačenost fenoloških karakteristika između rameta s povećanjem njihove starosti. Unutarklonska varijabilnost pripisuje se razlikama u uzgojnom obliku rameta (cijepova) i njihovoj različitoj dobi, odnosno njihovim kvantitavinim svojstvima (promjerom, visinom, razvijenošću), a nastalim i pod utjecajem pomotehničkih mjera.

\section{ZAKLJUČAK CONCLUSION}

Za fenološko svojstvo početka listanja u klonskoj sjemenskoj plantaži poljskog jasena utvrđena je statistički značajna razlika između svih istraživanih klonova, kao i za njihovu unutarpopulacijsku varijabilnost, no nisu utvrđene statistički značajne razlike između istraživanih populacija (Jasenovac, Novska i Stara Gradiška). Na osnovi fenoloških rezultata kroz sve tri istraživane godine, klonovi su podijeljeni na dvije ekotipske forme (rana i kasna) s obzirom na početak listanja, te je statistički potvrđena opravdanost razdvajanja na dvije forme. Uz temperaturne zahtjeve kao najbitnijem pokretačkom čimbeniku u ispoljavanju fenološkog svojstva listanja, u radu je dokazana visoka povezanost kumulativnih vrijednosti oborina (od 1. prosinca do nastupanja faze L2) na početak listanja $(\mathrm{r}=0,93)$. Unutarklonska varijabilnost ispitana kroz prosječne vrijednosti koeficijenta varijabilnosti (CV \%) za svojstvo listanja smanjivala se sa starošću pokusa i iznosila je prosječno $15,22 \%$ u dobi od $2+8$ god., $13,46 \%$ u dobi $2+10$ god. i 7,80 \% kod $2+11$ god., što ukazuje na veću stabilnost $\mathrm{i}$ ujednačenost fenoloških karakteristika između rameta s povećanjem njihove starosti.

\section{ZAHVALA}

\section{ACKNOWLEDGMENTS}

Istraživanja su izrađena u sklopu projekta „The role of biotic agents on vitality of narrow-leaved ash (Fraxinus angustifolia Vahl) in Croatian floodplain forests" - FRAXINPRO (IP-11-2013) i financirana od Hrvatske zaklade za znanost (HRZZ).

Zahvaljujemo se djelatnicima UŠP Nova Gradiška na svesrdnoj pomoći pri terenskim izmjerama.

\section{LITERATURA}

\section{REFERENCES}

- Anić, I., 2001: Uspijevanje i pomlađivanje sastojina poljskog jasena (Fraxinus angustifolia Vahl) u Posavini. Doktorska disertacija, Šumarski fakultet Sveučilišta u Zagrebu.

- Anić, I., 1999: Regeneration of narrow-leaved ash stands (Fraxinus angustifolia Vahl) in central Croatia. Glasnik za šumske pokuse, 34: 1-40. 
- Ballian, D., B. Jukić, B. Balić, D. Kajba, G. von Wuehlisch, 2015: Fenološka varijabilnost obične bukve (Fagus sylvatica L.) u međunarodnom pokusu provenijencija. Šumarski list, 11-12: 521-533.

- Basler, D., C. Korner, 2012: Photoperiod sensitivity of bud burst in 14 temperate forest tree species. Agric. For. Meteorol., 165: 73-81.

- Bogdan, S., D. Kajba, J. Franjić, M. Idžojtić, Ž. Škvorc, I. Katičić, 2007: Genetic variation in quantitative traits within and among Croatian narrow-leaved ash (Fraxinus angustifolia Vahl) populations assessed in an open-pollinated progeny test. Period. Biol., 109: 1-11.

- Bogdan, S., 2006: Varijabilnost posavskih populacija poljskog jasena (Fraxinus angustifolia Vahl) u testovima polusrodnika. Disertacija, Šumarski fakultet Zagreb.

- Caffarra, A., A. Donnelly, 2011: The ecological significance of phenology in four different tree species: effects of light and temperature on bud burst. Int. J. Biometeorol., 55: 711-721.

- Chuine, I., X. Morin, H. Bugmann, 2010: Warming, photoperiods, and tree phenology. Science, 329: 277-278.

- Estiarte, M., G. Puig, J. Penuelas, 2011: Large delay in flowering in continental versus coastal populations of a Mediterranean shrub, Globularia alypum. Int. J. Biometeorol., 55: 855-865.

- Franjić, J., K. Sever, S. Bogdan, Ž. Škvorc, D. Krstonošić, I. Alešković, 2011: Fenološka neujednačenost kao ograničavajući čimbenik uspješnoga oprašivanja u klonskim sjemenskim plantažama hrasta lužnjaka (Quercus robur L.). Croat. J. For. Eng. (32) 1: 141-156.

- Fraxigen, 2005: Ash Species in Europe: Biological Characteristics and Practical Guidelines for Sustainable Use. Oxford Forestry Institute, University of Oxford, United Kingdom

- Fu, Y.H., S. Piao, H. Zhao, S.J. Jeong, X. Wang, Y. Vitasse, P. Ciais, I.A. Janssens, 2014b: Unexpected role of winter precipitation in determining heat requirement for spring vegetation green-up at northern-middle and high latitudes. Glob. Chang. Biol., 12: 3743-3755.

- Fukarek, P., 1983: Poljski jasen. U: Potočić, Z. (ur.) Šumarska enciklopedija, Svezak II. Jugoslavenski leksikografski zavod „Miroslav Krleža“, Zagreb.

- Gross, A., P.L. Zaffarano, A. Duo, C.R. Grünig, 2012: Reproductive mode and life cycle of the ash dieback pathogen Hymenoscyphus pseudoalbidus. Fungal Genet. Biol., 49: 977-986.

- Heide, O.M., 2003: High autumn temperature delays spring bud burst in boreal trees, counterbalancing the effect of climatic warming. Tree Physiol., 23: 931-936.

- Heide, O.M., 1993: Daylength and thermal time responses of budburst during dormancy release in some northern deciduous trees. Physiol. Plant., 88: 531-540.

- Hänninen, H., 1990: Modelling bud dormancy release in trees from cool and temperate regions. Acta For. Fenn., 231: 1-47.

- Ivanković, M., M. Popović, I. Katičić, G. von Wuehlisch, S. Bogdan, 2011: Kvantitativna genetska varijabilnost provenijencija obične bukve (Fagus sylvatica L.) iz jugoistočne Europe. Sumar. list, 135(13): 25-37.

- Jelić, M., V. Vučetić, 2011: Utječe li promjena klime na početak cvjetanja jorgovana? Hrvatski meteorološki časopis, 46.

- Jochner, S., M. Alves-Eigenheer, A. Menzel, L.P.C. Morellato, 2013a: Using phenology to assess urban heat islands in tropical and temperate regions. Int. J. Climatol., 33: 3141-3151.
- Kajba, D., N. Pavičić, S. Bogdan, I. Katičić, 2008: Pomotechnical treatments in the broadleave clonal seed orchard. Lindgren, D. (ur.) Seed Orchard Conference, Umeå, 26-28 September 2007, 95-103., Sweden

- Körner, C., D. Basler, 2010: Phenology under global warming. Science, 327: 1461-1462.

- Kjær, E.D., L.V. McKinney, L.R. Nielsen, L.N. Hansen, J.K. Hansen, 2012: Adaptive potential of ash (Fraxinus excelsior) populations against the novel emerging pathogen Hymenoscyphus pseudoalbidus. Evol Appl., 5: 219-228.

- Kremer, A., O. Ronce, J.J. Robledo-Arnuncio, F. Guillaume, G. Bohrer, R. Nathan, J.R. Bridle, R. Gomulkiewicz, E.K. Klein, K. Ritland, 2012: Long-distance gene flow and adaptation of forest trees to rapid climate change. Ecol. Lett., 15(4): 378-392.

- Kramer, K., I. Leinonen, D. Loustau, 2000: The importance of phenology for the evaluation of impact of climate change on growth of boreal, temperate and Mediterranean forests ecosystems: an overview. Int. J. Biometeorol., 44: 67-75.

- Laube, J., T.H. Sparks, N. Estrella, J. Hofler, D.P. Ankerst, A. Menzel, 2014: Chilling outweighs photoperiod in preventing precocious spring development. Glob. Chang. Biol., 20: 170-182.

- Linkosalo, T., M.J. Lechowicz, 2006: Twilight far-red treatment advances leaf bud burst of silver birch (Betula pendula). Tree Physiol., 26: 1249-1256.

- McKinney, L.V., L.R. Nielsen, J.K. Hansen, E.D. Kjær, 2011: Presence of natural genetic resistance in Fraxinus excelsior (Oleaceae) to Chalara fraxinea (Ascomycota): an emerging infectious disease. Heredity, 106: 788-797.

- McKinney, L.V., I.M. Thomsen, E.D. Kjaer, L.R. Nielsen, 2012: Genetic resistance to Hymenoscyphus pseudoalbidus limits fungal growth and symptom occurrence in Fraxinus excelsior. Forest Pathology, 41 (1): 69-74.

- Menzel A., 2000: Trends in phenological phases in Europe between 1951 and 1996. Int. J. Biometeorol., 44(2): 76-81.

- Murray, M.B, M.G.R. Cannell, R.I. Smith, 1989: Date of budburst of fifteen tree species in Britain following climatic warming. J. Appl. Ecol., 26: 693-700.

- Peñuelas, J., C. Gordon, L. Llorens, T. Nielsen, A. Tietema, C. Beier, P. Bruna, B. Emmett, M. Estiarte, A. Gorissen, 2004: Nonintrusive field experiments show different plant responses to warming and drought among sites, seasons, and species in a north-south European gradient. Ecosystems, 7: 598-612.

- Peñuelas, J., I. Filella, P. Comas, 2002: Changed plant and animal life cycles from 1952 to 2000 in the Mediterranean region. Glob. Chang. Biol., 8: 531-544.

- Penzar, I., B. Penzar, 2000: Agrometeorologija, Školska knjiga, 228 str., Zagreb.

- Pliura, A., V. Lygis, Y. Suchockas, E. Bartevicius., 2011: Performance of twenty-four European excelsior populations in three Lithuanian progeny trials with a special emphasis on resistance to Chalara fraxinea. Baltic Forestry, 17: 17-33.

- Prpić B., P. Vratarić, Z. Seletković, 2005: Utjecaj snage rijeke na postanak i opstanak poplavnih šuma, Poplavne šume u Hrvatskoj, Akademija šumarskih znanosti, 168-177, Zagreb

- de Reaumur, R.A.F., 1735: Comparées avec celles qui ont été faites sous la ligne, à l'isle de France, à Alger et quelques unes de nos isles de l'Amérique., Memoires de l'Académie des Sciences de Paris, France 
- Shen, M., S. Piao, N. Cong, G. Zhang, I.A. Jassens, 2015: Precipitation impacts on vegetation spring phenology on the Tibetan Plateau. Glob. Chang. Biol., 21(10): 3647-3656.

- Sogaard, G., O. Johnsen, J. Nilsen, O. Junttila, 2008: Climatic control of bud burst in young seedlings of nine provenances of Norway spruce. Tree Physiol., 28: 311-320.
- Stener, L.G., 2013: Clonal differences in susceptibility to the dieback of Fraxinus excelsior L. In southern Sweden. Scandinavian Journal of Forest Research, 28, 3: 205-216.

- Temunović, M., 2013: Utjecaj ekoloških čimbenika na genetičku varijabilnost poljskog jasena (Fraxinus angustifolia Vahl, Oleaceae), Disertacija, Prirodoslovno-matematički fakultet, Zagreb.

\section{Summary}

Narrow-leaved ash (Fraxinus angustifolia Vahl) is a hygrophilic and predominantly thermophilic tree species that favours deep, clayed and moist soils exposed to occasional seasonal flooding. The largest complexes of narrow-leaved ash $(80 \%)$ are located along the Sava river. In the context of global climate change, it is important to know the composition and structure of genetic variability, particularly in terms of adaptive potential such as growth, survival and leaf phenology. The goal of research was to analyze the beginning of the leaf unfolding phase (L2 phase), the duration of leaf development (L2 - L6) and the impact of atmospheric parameters on the beginning of leaf unfolding, as well as to determine intrapopulation and interpopulation variability and the existence of ecotypic forms in relation to the beginning of leaf unfolding. Phenological characteristics of leaf phenology of narrow-leaved ash were monitored in the clonal seed orchard of Nova Gradiška in the course of three years of research (2012, 2014 and 2015). Monitoring included 42 clones originating from three populations (Jasenovac, Novska and Stara Gradiška). Every clone was represented with four ramets each (in total 168 plants). Leaf development was divided into six phenophases (figure 2, table 1); the analysis focused exclusively on Phase L2 (beginning of leaf unfolding). The average number of days from January 1st to the beginning of leaf unfolding was 98 days in 2012, 93 days in 2014, and 103 days in 2015 (figure 3, table 2). The average number of days required for leaf development amounted to 27 days in 2012, 26 days in 2014 and 20 days during 2015. Based on phenological results throughout the three years of study, the clones were divided into two ecotypic forms (early and late) with regard to the beginning of flushing (figure 5, table 4). The justification of division into two forms was statistically confirmed (table 3 ). The average values of the number of days for early ecotypic forms ranged from 90 to 101 days, and for late forms from 99 to 107 days. Along with temperature requirements as the most crucial activating factor in the manifestation of leaf phenology, researche also confirmed high correlation between cumulative values of precipitation quantity (from December $1^{\text {st }}$ to the beginning of Phase L2) and the beginning of leaf unfolding in narrow-leaved ash $(r=0,93)$. Statistically significant differences were found between all the studied clones, and so were for intrapopulation variability for the beginning of leaf unfolding; however, no statistically significant differences were found between the studied populations (table 3). Intraclonal values of the coefficient of variability (CV \%) for the property of leaf unfolding decreased with the age of the experiment and on average amounted to $15.22 \%$ at age $2+$ 8 years, $13.46 \%$ at age $2+10$ years, and $7.8 \%$ at age of $2+11$ years, indicating higher stability and uniformity of phenological characteristics among the ramets as their age increased (figure 4). The affiliation of the clones to ecotypic forms did not coincide with their geographic origin, which additionally confirmed important intrapopulation variability of narrow-leaved ash.

KEY WORDS: narrow-leaved ash, leaf unfolding, precipitation, intrapopulation and interpopulation variability, intraclonal variability, early and late ecotypic forms 